UDC 316.334 .23

LBC 60.561

\title{
AWARENESS OF SOCIAL ENTREPRENEURSHIP AMONG THE PUBLIC AND SMALL BUSINESSES: REGIONAL ASPECT ${ }^{1}$
}

\author{
Mariya B. Poltavskaya \\ Volgograd State University, Volgograd, Russian Federation
}

\begin{abstract}
The article reveals the study of awareness of social entrepreneurship among Volgograd citizens and representatives of small and medium-sized businesses of the Volgograd region. The authors specify the data of the eight-year all-Russian monitoring of public opinion of the Russians about social entrepreneurship, which show the lack of awareness of the Russians about social entrepreneurship. The empirical part of the article presents the data of two studies. First, the results of a mass formalized interview conducted in March-April 2018, $N=655$ people aged 18 years and older, the sample quota representing the sex and age composition of inner-city areas of Volgograd. Secondly, a mass formalized survey of 804 small and medium-sized entrepreneurs from 6 urban districts and 32 municipal districts of the Volgograd region, conducted in January-April 2018 by the Volgograd center for protection and development of business "Delo" with the support of the Department of Sociology of Volgograd State University. The data of the survey of the population of Volgograd as a whole repeat the trends identified by the all-Russian monitoring. The survey reveals that the awareness depends on age: the younger the Respondent, the more informed he is about social entrepreneurship. The type of activity affects awareness: twice as informed state and municipal employees, studying entrepreneurs, less aware are workers of large industrial enterprises, the unemployed, housewives. The level of material well-being affects awareness, one in five is informed among the better-off, one in twenty among the destitute. The gender of the Respondent has little impact on the level of awareness. In the mass consciousness of the population of Volgograd there is no well-formed idea of social entrepreneurship, its interpretation is implied in different meanings - from commercial activities to free aid, innovations are not correlated with social entrepreneurship.

Among small and medium-sized entrepreneurs of the Volgograd region there is no clearly formed idea of social entrepreneurship, it was difficult to determine for more than a quarter of the respondents. Having regard to the above the author concluds that the development of social entrepreneurship is possible only with the support of the government, legislative registration of the status of social entrepreneur, tax and property preferences.

Key words: social entrepreneurship, social entrepreneur, social enterprise, small business, public awareness, the Volgograd region.
\end{abstract}

УДК 316.334 .23

ББК 60.561

\section{ИНФОРМИРОВАННОСТЬ НАСЕЛЕНИЯ И ПРЕДСТАВИТЕЛЕЙ МАЛОГО БИЗНЕСА О СОЦИАЛЬНОМ ПРЕДПРИНИМАТЕЛЬСТВЕ: РЕГИОНАЛЬНЫЙ АСПЕКТ ${ }^{1}$}

\author{
Мария Борисовна Полтавская \\ Волгоградский государственный университет, г. Волгоград, Российская Федерация
}

Аннотация. Статья посвящена исследованию информированности о социальном предпринимательстве
волгоградцев и представителей малого и среднего бизнеса Волгоградской области. Приводятся данные восьми-
летнего всероссийского мониторинга общественного мнения россиян о социальном предпринимательстве, в
котором прослеживается отсутствие роста информированности россиян о социальном предпринимательстве.
Эмпирическую часть статьи представляют данные двух исследований. Во-первых, результаты массового фор- 
мализованного интервью, проведенного в марте - апреле 2018 г., $N=655$ человек в возрасте от 18 лет и старше, выборка квотная, репрезентирующая половозрастной состав внугригородских районов Волгограда. Во-вторых, массовый формализованный опрос 804 малых и средних предпринимателей из 6 городских округов и 32 муниципальных районов Волгоградской области, проведенный в январе - апреле 2018 г. «Волгоградским центром защиты и развития бизнеса “Дело”» при поддержке кафедры социологии ВолГУ. Данные опроса населения Волгограда в целом повторяют тенденции, выявленные всероссийским мониторингом. Установлено, что информированность зависит от возраста - чем моложе респондент, тем он более информирован о социальном предпринимательстве. На информированность влияет род деятельности - в два раза осведомленнее государственные и муниципальные служащие, обучающиеся, предприниматели, менее осведомлены работники крупных промышленных предприятий, безработные, домохозяйки. На информированность влияет уровень материального благосостояния, среди обеспеченных информирован каждый пятый, среди нуждающихся - каждый двадцатый. Пол респондента практически не влияет на уровень информированности. В массовом сознании населения Волгограда отсутствует четко сформированное представление о социальном предпринимательстве, в его трактовку вкладываются разные смыслы - от коммерческой деятельности до безвозмездной помощи, инновации не соотносятся населением с социальным предпринимательством.

Среди малых и средних предпринимателей Волгоградской области также не сформировано ясного представления о социальном предпринимательстве, затруднились его определить более четверти опрошенных. Делается вывод, что развитие социального предпринимательства возможно только при поддержке со стороны государства, законодательном оформлении статуса социального предпринимателя, налоговых и имущественных преференциях.

Ключевые слова: социальное предпринимательство, социальный предприниматель, социальное предприятие, малый бизнес, информированность населения, Волгоградская область.

Введение. Социальное предпринимательство - новая, еще не прошедшая процесс институционализации, практика деятельности, лежащая на стыке двух систем общества - экономической и социальной. Субъектами социального предпринимательства могут быть как некоммерческие организации третьего сектора, так и коммерческие предприятия, работающие в социальной сфере.

Одной из особенностей социального предпринимательства является гибридный характер деятельности, который заключается в «двойной результативности» (англ. double bottom-line), то есть в стремлении к одновременному достижению социального и экономического блага, социального и экономического эффектов [10; 11$]$.

Согласно определению ОЭСР «социальное предпринимательство имеет в качестве основной цели решение неотложных социальных проблем и удовлетворение общественных потребностей инновационным способом, одновременно обеспечивая общий интерес и общее благо в интересах сообщества. Иными словами, социальное предпринимательство нацелено, прежде всего, на социальное воздействие, на результативность, а не на максимизацию прибыли» [3].
В России данную проблематику исследуют в Центре социального предпринимательства и социальных инноваций Высшей школы экономики $[1 ; 2 ; 4]$. На сегодняшний день в РФ понятия «социальное предпринимательство», «социальное предприятие», статус социального предпринимателя законодательно не оформлены - отсутствуют законодательные акты, определяющие и регламентирующие эту деятельность и описывающие ее особенность.

Тем не менее социальное предпринимательство развивается, инициируются социально значимые проекты, которые финансово окупаются, однако эта практика не носит массовый характер, как правило, модели социального предпринимательства локальны, зачастую уникальны, а не универсальны.

Мониторинг общественного мнения россиян о социальном предпринимательстве. Всероссийские опросы населения о социальном предпринимательстве начали проводиться Исследовательской группой ЦИРКОН при подлержке фонда региональных социальных проектов «Наше будущее». Опросы были проведены в 2008, 2011, 2012, 2013, 2015, 2016 гг., то есть можно говорить о мониторинге общественного мнения о социальном предпринимательстве на протяжении восьми 


\section{СОЦИОЛОГИЯ И СОЦИАЛЬНЫЕ ТЕХНОЛОГИИ}

лет [5-8]. В 2013 и 2018 гг. были проведены исследования автопортрета социального предпринимателя в России [9].

Если в 2008 г. $73 \%$ россиян отвечали, что впервые слышат о социальном предпринимательстве, что-то слышали $20,0 \%$, знают о нем $6,0 \%$, затруднились ответить $2,0 \%$, то через восемь лет картина не сильно изменилась. Исследователи ЦИРКОН отметили отсутствие роста информированности россиян о социальном предпринимательстве на протяжении восьми лет измерений (рис. 1).

Отсутствие роста информированности, по мнению экспертов, свидетельствует о том, что социальное предпринимательство так и не стало значимым общественным явлением, «оставаясь в фокусе внимания сравнительно узкой категории причастных к теории или практике социального предпринимательства экспертов и специалистов. За годы измерений лишь 4-7 \% респондентов всероссийских опросов уверенно заявляли о своей осведомленности о том, что такое "социальное предпринимательство”, в 2016 г. - 6 \%» [8].
Методика исследования. Чтобы охарактеризовать уровень информированности населения Волгограда о социальном предпринимательстве, обратимся к эмпирическим данным. В марте - апреле 2018 г. нами было проведено исследование методом массового формализованного интервью. В нем приняли участие 655 человек в возрасте от 18 лет и старше. Выборка стратифицированная, квотная, репрезентирующая половозрастной состав внутригородских районов Волгограда. Квоты по полу, возрасту и месту жительства рассчитывались на основе данных, представленных на сайте Территориального органа Федеральной службы государственной статистики по Волгоградской области (http:// www.gks.ru).

Результаты. Респондентам задавался вопрос «Знаете ли Вы, что-либо слышали или слышите сейчас впервые словосочетание "социальное предпринимательство"?». Только $6,9 \%$ всех опрошенных утвердительно ответили, что знают и слышали о социальном предпринимательстве (табл. 1).

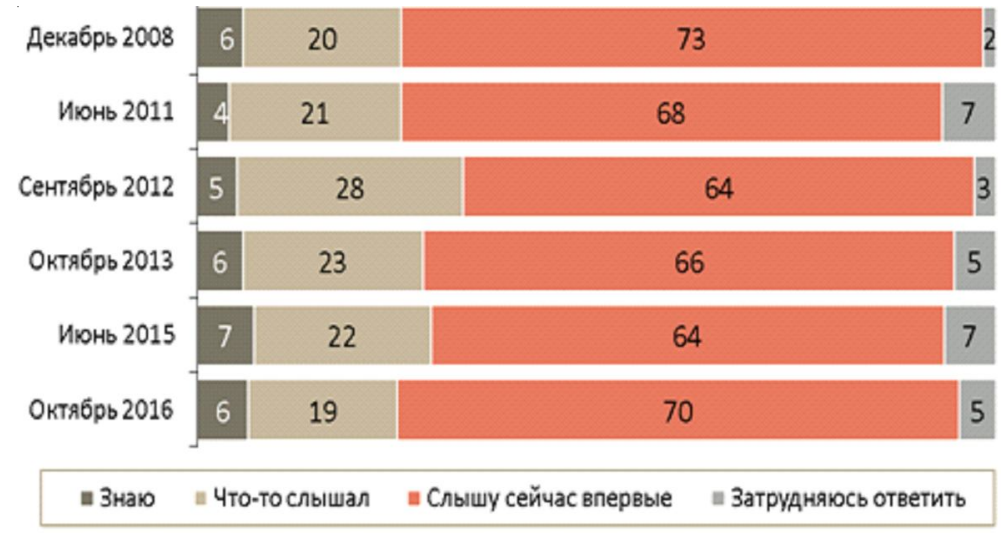

Рис. 1. Распределение ответов на вопрос «Знаете ли Вы, что-либо слышали или слышите сейчас впервые словосочетание “социальное предпринимательство”?» в опросах ЦИРКОН 2008-2016 гг., \% [8]

Таблииа 1

Информированность о социальном предпринимательстве в зависимости от пола

\begin{tabular}{|l|l|c|c|c|}
\hline \multicolumn{1}{|c|}{ Ответ } & \multicolumn{1}{|c|}{ Показатель } & Мужской & Женский & Всего \\
\hline \multirow{2}{*}{ Знаю } & Количество & 16 & 29 & 45 \\
\cline { 2 - 5 } & $\%$ & 5,4 & 8,1 & 6,9 \\
\hline \multirow{2}{*}{ Что-то слышал } & Количество & 54 & 75 & 129 \\
\cline { 2 - 5 } & $\%$ & 18,2 & 20,9 & 19,7 \\
\hline $\begin{array}{l}\text { Слышу сейчас } \\
\text { впервые }\end{array}$ & Количество & 161 & 196 & 357 \\
\hline \multirow{2}{*}{$\begin{array}{l}\text { Затрудняюсь } \\
\text { ответить }\end{array}$} & Количество & 54,2 & 54,7 & 54,5 \\
\hline \multirow{2}{*}{ Всего } & $\%$ & 22,2 & 58 & 124 \\
\cline { 2 - 5 } & Количество & 297 & 16,2 & 18,9 \\
\cline { 2 - 5 } & $\%$ & 100,0 & 100,0 & 655 \\
\hline
\end{tabular}


Среди осведомленных женщин немного больше $(8,1 \%)$, чем мужчин $(5,4$ \%). «Чтото слышал» о социальном предпринимательстве примерно каждый пятый опрошенный (19,7\%), мужчин и женщин среди них примерно равное количество - 18,2 и $20,9 \%$ соответственно. Впервые слышат о социальном предпринимательстве более половины опрошенных - 54,5 \%, причем мужчин и женщин практически поровну. Примерно каждый пятый затруднился с ответом (18,9\%), среди них мужчин незначительно больше $(22,2 \%)$, чем женщин (16,2%). Таким образом, фактор пола не оказывает сильного влияния на уровень информированности населения Волгограда.

Зависимость уровня информированности населения от возраста представлена в таблице 2.
Среди тех, кто знает о социальном предпринимательстве, больше молодежи до 24 лет (10,2 \%), среди 40-49-летних и тех, кто старше 60 лет, знающих в два раза меньше - 3,8 \% и 4,5\% соответственно. Молодежь до 24 лет и те, кому свыше 60 лет, «что-то слышали» о социальном предпринимательстве чаще, чем другие возрастные категории населения: 25,8 \% - до 24 лет, 18,9 \% - 25-29 лет, 17,0 \% 30-39 лет, 12,4 \% - 40-49 лет, 15,4\% - 5059 лет, 25,0 \% - старше 60 лет. Наименее информированными оказались возрастные категории 25-29 лет - 64,9 \%, 40-49 лет - 64,8 \%, к которым относится молодежь, как правило, уже закончившая учебные заведения, а также представители трудоспособного возраста. Таким образом, фактор возраста более значим при оценке информированности населения, чем фактор пола. Среди молодежи до

Таблица 2

\section{Информированность о социальном предпринимательстве в зависимости от возраста}

\begin{tabular}{|c|c|c|c|c|c|c|c|c|}
\hline \multirow[t]{2}{*}{ Ответ } & \multirow[t]{2}{*}{ Показатель } & \multicolumn{6}{|c|}{ Возраст, лет } & \multirow[t]{2}{*}{ Всего } \\
\hline & & до 24 & $25-29$ & $30-39$ & $40-49$ & $50-59$ & свыше 60 & \\
\hline \multirow{2}{*}{ Знаю } & Количество & 13 & 4 & 11 & 4 & 6 & 7 & 45 \\
\hline & $\%$ & 10,2 & 10,8 & 9,8 & 3,8 & 5,1 & 4,5 & 6,9 \\
\hline \multirow{2}{*}{ Что-то слышал } & Количество & 33 & 7 & 19 & 13 & 18 & 39 & 129 \\
\hline & $\%$ & 25,8 & 18,9 & 17,0 & 12,4 & 15,4 & 25,0 & 19,7 \\
\hline \multirow{2}{*}{$\begin{array}{l}\text { Слышу сейчас } \\
\text { впервые }\end{array}$} & Количество & 59 & 24 & 61 & 68 & 60 & 85 & 357 \\
\hline & $\%$ & 46,1 & 64,9 & 54,5 & 64,8 & 51,3 & 54,5 & 54,5 \\
\hline \multirow{2}{*}{$\begin{array}{l}\text { Затрудняюсь } \\
\text { ответить }\end{array}$} & Количество & 23 & 2 & 21 & 20 & 33 & 25 & 124 \\
\hline & $\%$ & 18,0 & 5,4 & 18,8 & 19,0 & 28,2 & 16,0 & 18,9 \\
\hline \multirow{2}{*}{ Всего } & Количество & 128 & 37 & 112 & 105 & 117 & 156 & 655 \\
\hline & $\%$ & 100,0 & 100,0 & 100,0 & 100,0 & 100,0 & 100,0 & 100,0 \\
\hline
\end{tabular}

Таблица 3

\section{Информированность о социальном предпринимательстве в зависимости} от рода деятельности

\begin{tabular}{|c|c|c|c|c|c|c|c|c|c|c|c|}
\hline \multirow[b]{2}{*}{ Ответ } & \multirow[b]{2}{*}{ Показатель } & \multicolumn{9}{|c|}{ Род деятельности } & \multirow[b]{2}{*}{ Всего } \\
\hline & & $\begin{array}{c}\text { Обучаюсь } \\
\text { в образова- } \\
\text { тельном уч- } \\
\text { реждении }\end{array}$ & $\begin{array}{c}\text { Работаю } \\
\text { в сфере } \\
\text { торгов- } \\
\text { ли, ус- } \\
\text { луг }\end{array}$ & $\begin{array}{c}\text { Работаю на } \\
\text { крупном } \\
\text { промыш- } \\
\text { ленном } \\
\text { предприятии }\end{array}$ & $\begin{array}{c}\text { Работаю } \\
\text { в бюд- } \\
\text { жетной } \\
\text { сфере }\end{array}$ & $\begin{array}{c}\text { Предпри- } \\
\text { ниматель, } \\
\text { имею } \\
\text { свой биз- } \\
\text { нес }\end{array}$ & $\begin{array}{c}\text { Государ- } \\
\text { ствен- } \\
\text { ный/муни } \\
\text { ципаль- } \\
\text { ный слу- } \\
\text { жащий }\end{array}$ & $\begin{array}{l}\text { Пен- } \\
\text { сио- } \\
\text { нер }\end{array}$ & $\begin{array}{c}\text { Безра- } \\
\text { ботный, } \\
\text { домохо- } \\
\text { зяйка }\end{array}$ & Другое & \\
\hline \multirow{2}{*}{ Знаю } & Количество & 14 & 8 & 2 & 3 & 5 & 7 & 6 & 0 & 0 & 45 \\
\hline & $\%$ & 13,0 & 6,0 & 3,0 & 3,9 & 12,8 & 15,9 & 4,0 & 0,0 & 0,0 & 6,9 \\
\hline \multirow{2}{*}{$\begin{array}{l}\text { Что-то слы- } \\
\text { шал }\end{array}$} & Количество & 24 & 27 & 11 & 9 & 6 & 10 & 36 & 3 & 3 & 129 \\
\hline & $\%$ & 22,2 & 20,3 & 16,7 & 11,8 & 15,4 & 22,7 & 23,8 & 12,0 & 23,1 & 19,7 \\
\hline \multirow{2}{*}{$\begin{array}{l}\text { Слышу сей- } \\
\text { час впервые }\end{array}$} & Количество & 47 & 79 & 42 & 45 & 21 & 21 & 79 & 15 & 8 & 357 \\
\hline & $\%$ & 43,5 & 59,4 & 63,6 & 59,2 & 53,8 & 47,7 & 52,3 & 60,0 & 61,5 & 54,5 \\
\hline \multirow{2}{*}{$\begin{array}{l}\text { Затрудняюсь } \\
\text { ответить }\end{array}$} & Количество & 23 & 19 & 11 & 19 & 7 & 6 & 30 & 7 & 2 & 124 \\
\hline & $\%$ & 21,3 & 14,3 & 16,7 & 25,0 & 17,9 & 13,6 & 19,9 & 28,0 & 15,4 & 18,9 \\
\hline \multirow{2}{*}{ Всего } & Количество & 108 & 133 & 66 & 76 & 39 & 44 & 151 & 25 & 13 & 655 \\
\hline & $\%$ & 100,0 & 100,0 & 100,0 & 100,0 & 100,0 & 100,0 & 100,0 & 100,0 & 100,0 & 100,0 \\
\hline
\end{tabular}


30 лет в два раза больше тех, кто знает о социальном предпринимательстве, чем среди 50-летних и старше.

Род деятельности оказывает влияние на уровень информированности (табл. 3). Наиболее информированы о социальном предпринимательстве государственные и муниципальные служащие $(15,9 \%)$, среди обучающихся $(13,0 \%)$ и предпринимателей $(12,8 \%)$ осведомленных о социальном предпринимательстве в несколько раз больше, чем среди работающих в сфере торговли и услуг $(6,0 \%)$, в бюджетной сфере $(3,9 \%)$, пенсионеров $(4,0 \%)$ и работников крупных промышленных предприятий $(3,0 \%)$.

Совсем не информированы безработные и домохозяйки. Более других «что-то слышали» пенсионеры (23,8 \%), государственные и муниципальные служащие (22,7 \%), обучающиеся $(22,2 \%)$, работники сферы торговли и услуг $(20,3 \%)$.

Среди не информированных, которые «слышат сейчас впервые», больше всего работников крупных промышленных предприятий $(63,6 \%)$, безработных и домохозяек $(60,0 \%)$, работников сферы торговли и услуг (59,4\%).

Таким образом, наиболее информированы о социальном предпринимательстве государственные и муниципальные служащие, обучающиеся, предприниматели, а менее всего-работники крупных промышленных предприятий, безработные, домохозяйки, работники сферы торговли и услуг.
Зависимость информированности от материального положения представлена в таблице 4.

Среди тех, кто не испытывает материальных затруднений, а таковых в выборке оказалось 21 чел., знают о социальном предпринимательстве - 23,8 \%, что-то слышали $-14,3 \%$, слышат впервые $-33,3 \%$, затруднились ответить $-28,6 \%$. Среди тех, кто живет по принципу «денег хватает на все, кроме покупки недвижимости» (63 чел.), осведомленных $-15,5 \%$, частично осведомленных - 30,2 \%, слышат сейчас впервые $44,4 \%$, затруднились ответить $-9,5 \%$. А вот среди нуждающихся («на питание денег хватает, но покупка одежды вызывает затруднения») знающих о социальном предпринимательстве в несколько раз меньше $4,4 \%$, среди тех, кому «денег хватает на питание, одежду и мелкую бытовую технику, но купить сейчас телевизор было бы затруднительно», знающих также немного $5,7 \%$. Следовательно, чем выше уровень материального благосостояния, тем выше информированность о социальном предпринимательстве.

На открытый вопрос «Как Вы думаете, кто такие социальные предприниматели? Объясните, пожалуйста, как Вы это понимаете?» ответили 137 чел. (на него отвечали те, кто «знают» и «что-то слышали» о социальном предпринимательстве (174 чел.), что составляет $79 \%$.

Информированность о социальном предпринимательстве

Таблица 4 в зависимости от материального положения

\begin{tabular}{|c|c|c|c|c|c|c|c|c|}
\hline \multirow[b]{2}{*}{ Ответ } & \multirow[b]{2}{*}{ Показатель } & \multicolumn{6}{|c|}{ Материальное положение } & \multirow[b]{2}{*}{ Всего } \\
\hline & & $\begin{array}{c}\text { Денег с тру- } \\
\text { дом хватает } \\
\text { даже на пи- } \\
\text { тание }\end{array}$ & $\begin{array}{c}\text { На питание } \\
\text { денег хватает, } \\
\text { но покупка } \\
\text { одежды вызы- } \\
\text { вает затрудне- } \\
\text { ния }\end{array}$ & $\begin{array}{c}\text { Денег хватает на } \\
\text { питание, одежду } \\
\text { и мелкую быто- } \\
\text { вую технику, но } \\
\text { купить сейчас } \\
\text { телевизор было } \\
\text { бы затрудни- } \\
\text { тельно }\end{array}$ & $\begin{array}{c}\text { Денег хвата- } \\
\text { ет на круп- } \\
\text { ную быто- } \\
\text { вую техни- } \\
\text { ку, но мы не } \\
\text { могли бы } \\
\text { купить но- } \\
\text { вую машину }\end{array}$ & $\begin{array}{c}\text { Денег хвата- } \\
\text { ет на все, } \\
\text { кроме по- } \\
\text { купки не- } \\
\text { движимости } \\
\text { (квартиры } \\
\text { или дачи) }\end{array}$ & $\begin{array}{c}\text { Материальных } \\
\text { затруднений } \\
\text { не испытыва- } \\
\text { ем. При необ- } \\
\text { ходимости } \\
\text { могли бы ку- } \\
\text { пить дачу, } \\
\text { квартиру } \\
\end{array}$ & \\
\hline \multirow{2}{*}{ Знаю } & Количество & 1 & 6 & 17 & 6 & 10 & 5 & 45 \\
\hline & $\%$ & 2,4 & 4,4 & 5,7 & 6,2 & 15,9 & 23,8 & 6,9 \\
\hline \multirow{2}{*}{$\begin{array}{l}\text { Что-то слы- } \\
\text { шал }\end{array}$} & Количество & 7 & 19 & 59 & 22 & 19 & 3 & 129 \\
\hline & $\%$ & 17,1 & 14,0 & 19,9 & 22,7 & 30,2 & 14,3 & 19,7 \\
\hline \multirow{2}{*}{$\begin{array}{l}\text { Слышу сей- } \\
\text { час впервые }\end{array}$} & Количество & 24 & 85 & 163 & 50 & 28 & 7 & 357 \\
\hline & $\%$ & 58,5 & 62,5 & 54,9 & 51,5 & 44,4 & 33,3 & 54,5 \\
\hline \multirow{2}{*}{$\begin{array}{l}\text { Затрудняюсь } \\
\text { ответить }\end{array}$} & Количество & 9 & 26 & 58 & 19 & 6 & 6 & 124 \\
\hline & $\%$ & 22,0 & 19,1 & 19,5 & 19,6 & 9,5 & 28,6 & 18,9 \\
\hline \multirow{2}{*}{ Всего } & Количество & 41 & 136 & 297 & 97 & 63 & 21 & 655 \\
\hline & $\%$ & 100,0 & 100,0 & 100,0 & 100,0 & 100,0 & 100,0 & 100,0 \\
\hline
\end{tabular}


Ответы на открытый вопрос сгруппированы в блоки по доминирующим признакам социального предпринимательства (табл. 5). Сразу поясним, что «Благотворительность и меценатство», «Мошенники»- это блоки, включающие неверную трактовку социального предпринимательства.

В определениях социального предпринимательства, которые давали участники опроca, нашли свое место создание рабочих мест для социально незащищенных слоев населения, стремление к решению социально значимых проблем, оказание социальных услуг. Однако отметим, что такой важный признак социального предпринимательства, как новаторство, инновационность не был отмечен ни разу. Довольно устойчива тенденция отождествления социального предпринимательства с благотворительностью и меценатством - так считает каждый пятый, что является неверным мнением. Недоверие к социальному предпринимательству представлено его трактовкой как «мошенничества, обмана, наживы». Таким образом, ключевыми характеристиками социального предпринимательства население считает социальную миссию, не выделяя экономическую устойчивость и новаторство как характеристики социального предпринимательства.

Поскольку социально ориентированные некоммерческие организации могут выступать субъектами социального предпринимательства, вести деятельность, приносящую доход, для нас важны данные, полученные при ответе на вопрос «Вы считаете правильным, что некоммерческие организации предоставляют свои услуги платно или ведут предпринимательскую деятельность?» (см. табл. 6).

Рассмотрим влияние фактора пола и возраста при ответе на этот вопрос. В целом, независимо от возраста и пола, 36,6 \% опрошенных считают правильным, что некоммерческие организации предоставляют свои услуги платно или ведут предпринимательскую деятельность (сумма ответов тех, кто указал «да» и «скорее да, чем нет»), а вот 47,7 \% полагают, что «скорее нет, чем да» и «нет», 15,7 \% затруднились ответить. Таким образом, в представлении большинства населения (почти половина опрошенных) некоммерческие организации не должны вести предпринимательскую деятельность и оказывать услуги платно.

Таблица 5

Трактовка социального предпринимательства населением Волгограда

\begin{tabular}{|c|c|c|}
\hline $\begin{array}{l}\text { Доминирующие признаки соци- } \\
\text { ального предпринимательства }\end{array}$ & Примеры определений & $\begin{array}{l}\text { \% (от ответив- } \\
\text { ших } 137 \text { чел.) }\end{array}$ \\
\hline $\begin{array}{l}\text { Приоритет социальной } \text { мис- } \\
\text { сии над прибылью }\end{array}$ & $\begin{array}{l}\text { «редприниматели, которые решают социально-значимые } \\
\text { цели и проблемы», «тип предпринимателей, которые ставят } \\
\text { своей главной целью помощь другим людям», «предпри- } \\
\text { ниматели, которые находятся в активном взаимодействии с } \\
\text { социумом», «главное не заработок, а решение социальных } \\
\text { проблем», «действуют без личной выгоды» }\end{array}$ & 46 \\
\hline $\begin{array}{l}\text { Создание рабочих мест и } \\
\text { обеспечение занятости соци- } \\
\text { ально незащищенных групп }\end{array}$ & $\begin{array}{l}\text { «Кто привлекает людей с ограниченными возможностями», } \\
\text { «помощь другим людям в трудоустройстве», «трудоуст- } \\
\text { ройство инвалидов», «люди, помогающие социально неза- } \\
\text { щищенным» }\end{array}$ & 10 \\
\hline Коммерческая эффективность & $\begin{array}{l}\text { «Бизнес, который приносит доход», «вид бизнеса, прино- } \\
\text { сящий прибыль и решающий социальные проблемы» }\end{array}$ & 9 \\
\hline Оказание социальных услуг & $\begin{array}{l}\text { «Предприниматели, которые оказывают социальные услу- } \\
\text { ги», «направленность на оказание социальных услуг» }\end{array}$ & 6,5 \\
\hline $\begin{array}{l}\text { Благотворительность, } \\
\text { натство }\end{array}$ & $\begin{array}{l}\text { «Предприниматели, которые занимаются благотворительно- } \\
\text { стью», «безвозмездная помощь населению в решении проблем } \\
\text { общества», «меценаты от бизнеса», «добрые люди, предпри- } \\
\text { ниматели» }\end{array}$ & 20,5 \\
\hline Мошенники & $\begin{array}{l}\text { «Мошенники», «наживаются на других», «обманывают } \\
\text { других», «обманщики» }\end{array}$ & 5 \\
\hline Другое & $\begin{array}{l}\text { «Бездельники», «маршрутчики», «занимаются продоволь- } \\
\text { ствием», «занимаются опекой» }\end{array}$ & 3 \\
\hline \multicolumn{2}{|l|}{ Итого } & 100 \\
\hline
\end{tabular}


Распределение ответов на вопрос «Вы считаете правильным, что некоммерческие организации предоставляют свои услуги платно или ведут предпринимательскую деятельность?» в зависимости от возраста и пола, \%

\begin{tabular}{|c|c|c|c|c|c|c|c|}
\hline Возраст & Пол & Да & $\begin{array}{c}\text { Скорее да, } \\
\text { чем нет }\end{array}$ & $\begin{array}{c}\text { Скорее нет, } \\
\text { чем да }\end{array}$ & Нет & $\begin{array}{c}\text { Затрудняюсь } \\
\text { ответить }\end{array}$ & Всего \\
\hline \multirow[t]{3}{*}{ До 24} & Муж. & 17,5 & 22,2 & 12,7 & 25,4 & 22,2 & 100,0 \\
\hline & Жен. & 15,4 & 40,0 & 10,8 & 18,5 & 15,4 & 100,0 \\
\hline & Всего & 16,4 & 31,3 & 11,7 & 21,9 & 18,8 & 100,0 \\
\hline \multirow[t]{3}{*}{ 25-29 лет } & Муж. & 14,3 & 33,3 & 9,5 & 19,0 & 23,8 & 100,0 \\
\hline & Жен. & 6,3 & 31,3 & 25,0 & 31,3 & 6,3 & 100,0 \\
\hline & Всего & 10,8 & 32,4 & 16,2 & 24,3 & 16,2 & 100,0 \\
\hline \multirow[t]{3}{*}{ 30-39 лет } & Муж. & 16,4 & 32,7 & 16,4 & 20,0 & 14,5 & 100,0 \\
\hline & Жен. & 17,5 & 17,5 & 26,3 & 22,8 & 15,8 & 100,0 \\
\hline & Всего & 17,0 & 25,0 & 21,4 & 21,4 & 15,2 & 100,0 \\
\hline \multirow[t]{3}{*}{ 40-49 лет } & Муж. & 17,0 & 25,0 & 21,4 & 21,4 & 15,2 & 100,0 \\
\hline & Жен. & 7,3 & 20,0 & 36,4 & 27,3 & 9,1 & 100,0 \\
\hline & Всего & 10,5 & 22,9 & 27,6 & 21,9 & 17,1 & 100,0 \\
\hline \multirow[t]{3}{*}{ 50-59 лет } & Муж. & 13,2 & 18,9 & 20,8 & 35,8 & 11,3 & 100,0 \\
\hline & Жен. & 14,1 & 20,3 & 32,8 & 18,8 & 14,1 & 100,0 \\
\hline & Всего & 13,7 & 19,7 & 27,4 & 26,5 & 12,8 & 100,0 \\
\hline \multirow{3}{*}{$\begin{array}{l}\text { Свыше } \\
60 \text { лет }\end{array}$} & Муж. & 14,5 & 10,9 & 29,1 & 32,7 & 12,7 & 100,0 \\
\hline & Жен. & 5,0 & 22,8 & 13,9 & 42,6 & 15,8 & 100,0 \\
\hline & Всего & 8,3 & 18,6 & 19,2 & 39,1 & 14,7 & 100,0 \\
\hline \multirow[t]{3}{*}{ Всего } & Всего муж. & 15,2 & 22,9 & 18,5 & 25,6 & 17,8 & 100,0 \\
\hline & Всего жен. & 10,9 & 24,6 & 22,6 & 27,9 & 14,0 & 100,0 \\
\hline & Итого & 12,8 & 23,8 & 20,8 & 26,9 & 15,7 & 100,0 \\
\hline
\end{tabular}

Однако чем моложе респонденты, тем чаще они отвечали, что для НКО правильно предоставлять свои услуги платно и вести предпринимательскую деятельность - в возрасте до 24 лет так считают 47,7\% (сумма ответов «да» и «скорее да, чем нет»), 2529 лет - 43,2 \%, в возрасте 50-59 лет - таковых уже 33,4 \%, а свыше 60 лет почти в два раза меньше - 26,9\%.

В то же время пожилые люди чаще высказывали мнение, что для НКО неправильно предоставлять услуги платно или вести предпринимательскую деятельность (сумма ответов «скорее нет, чем да» и «нет») - свыше 60 лет так считают 58,3 \%, среди 50-59-летних $-53,9 \%, 25-29$-летних - 40,5\%, до 24 лет $-33,6 \%$.

Среди старших возрастных групп мужчины чаще женщин высказывали мнение, что для НКО неправильно предоставлять услуги платно или вести предпринимательскую деятельность (сумма ответов «скорее нет, чем да» и «нет») 56,6 \% мужчин 5059 лет, 61,8 \% мужчин свыше 60 лет, в то время как женщин в возрасте 50-59 лет так считает 51,6\%, а старше 60 лет - 56,5\%.
Такая же ситуация и среди молодежи до 24 лет - мужчины $38,1 \%$, женщины $29,3 \%$. В целом среди опрошенных без учета возраста более половины составляют женщины - 50,5 \%, и 44,1 \% мужчин считают неправильным предоставлять услуги платно или вести предпринимательскую деятельность.

Гораздо больше женщин до 24 лет $(55,4 \%)$ высказываются «да» и «скорее да, чем нет», мужчин с таким мнением в этом возрасте только $39,7 \%$. А вот уже в возрасте 24-29 лет мужчин, ответивших «да» и «скорее да, чем нет», больше $-47,6 \%$, в то время как женщин $-37,6 \%$.

Таким образом, оценивая информированность населения Волгограда о социальном предпринимательстве, можно отметить, что полученные данные соотносятся с данными всероссийских опросов ЦИРКОН. Фиксируется низкий уровень информированности населения Волгограда о социальном предпринимательстве. При анализе данных необходимо учитывать фактор возраста, рода деятельности, материального положения, пола респондентов. 
М.Б. Полтавская. Информированность населения о социальном предпринимательстве

Информированность малого и среднего бизнеса Волгоградской области о социальном предпринимательстве. Методика исследования. Для характеристики информированности представителей малого и среднего бизнеса приведем данные другого исследования - опроса, который был проведен «Волгоградским центром защиты и развития бизнеса “Дело”» при поддержке кафедры социологии Волгоградского государственного университета. В выборку вошли 804 предпринимателя из 6 городских округов (Волгоград, Волжский, Камышин, Михайловка, Урюпинск, Фролово) и 32 муниципальных районов Волгоградской области, метод исследования: формализованный опрос, январь - апрель 2018 года. Данный опрос не является репрезентативным, поскольку респондентами выступили представители предпринимательского сообщества, которые имели опыт межсекторного взаимодействия - с органами власти и некоммерческим сектором. Полученные данные отражают мнение активной части предпринимателей малого и среднего бизнеса Волгоградской области, которые охотно идут на контакт с представителями некоммерческих структур и госу- дарственных органов, готовы к межсекторному взаимодействию.

Результаты. Сферы деятельности малых предпринимателей разнообразны, однако традиционно доминирует розничная торговля $-40,9 \%$ (рис. 2). Поскольку на вопрос был возможен множественный ответ, итоговая сумма не равна $100 \%$.

Бытовые услуги оказывают 13,1 \%, в сфере сельского хозяйства работают 10,8\%, общественным питанием занимаются 8,7 \% предприятий, услуги транспорта и связи оказывают 8,5 \% предприятий, в сфере строительства 5,8 \% предприятий, услуги для бизнеса оказывают 4,5\%, заняты в секторах оптовой торговли - 3,6 \%, промышленности 1,9 \%. Другими видами деятельности заняты 9,5 \% опрошенных предпринимателей.

Что касается размеров организаций, то предприятия микробизнеса составили большинство - 64,3 \%, малого бизнеса - 32,3\%, среднего - 1,9\%, затруднились классифицировать по размеру свое предприятие 1,5 \% опрошенных предпринимателей.

Перспективы развития своего бизнеса на ближайшие три года предприниматели оценили следующим образом (табл. 7).

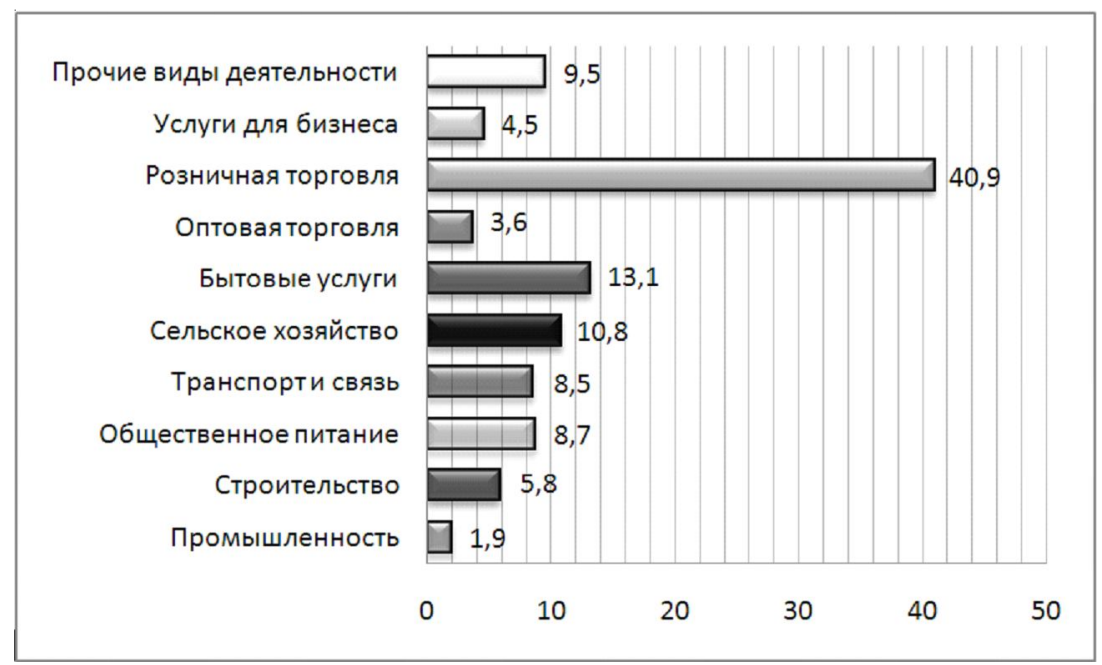

Рис. 2. Сферы деятельности предприятий, \%

Оценка перспектив развития бизнеса на ближайшие три года

\begin{tabular}{|l|c|}
\hline \multicolumn{1}{|c|}{ Оценка перспектив развития бизнеса на ближайшие три года } & Результат, \% \\
\hline Перспективы хорошие. Мой бизнес будет развиваться & 20,1 \\
\hline $\begin{array}{l}\text { Перспектив развития нет. Мой бизнес останется на прежнем } \\
\text { уровне }\end{array}$ & 48,6 \\
\hline Перспективы плохие. Мой бизнес может понести убытки & 28,9 \\
\hline Затруднились ответить & 2,4 \\
\hline
\end{tabular}




\section{СОЦИОЛОГИЯ И СОЦИАЛЬНЫЕ ТЕХНОЛОГИИ}

Примерно половина опрошенных предпринимателей $(48,6 \%)$ считают, что перспективы развития бизнеса отсутствуют, в течение этого времени бизнес останется на прежнем уровне. Каждый пятый предприниматель полагает, что перспективы хорошие, их бизнес будет развиваться $(20,1 \%)$. Перспективы бизнеса оценивают негативно и считают, что они могут понести убытки 28,9\%. Затруднились с оценкой $2,4 \%$ опрошенных. Таким образом, оценку перспектив развития бизнеса можно назвать «умеренно пессимистичной».

Ответы на вопрос «Как Вы думаете, что представляет собой социальное предпринимательство?» представлены на рисунке 3 .

Примерно четверть опрошенных предпринимателей $(26,1$ \%) затруднились определить, что представляет собой социальное предпринимательство. Большинство предпринимателей считают, что это бизнес, занимающийся решением социальных проблем / вкладывающий деньги в социальную сферу, оказывающий помощь населению (34,7 \%).

На втором месте оказалось понятие социального предпринимательства как «Созда- ние рабочих мест (в том числе для инвалидов, малоимущих, социально незащищенных слоев)» - 22,5 \%. Что это «люди, работающие на благо общества, населения России» считают 21,1 \% предпринимателей, $13,3 \%$ респондентов полагают, что это «бизнес в социальной сфере, предоставление социальных услуг на коммерческой основе» (социальное предпринимательство следует отличать от бизнеса в социальной сфере); 9,6 \% опрошенных ответили, что социальное предпринимательство - это «выпуск продукции по низким, доступным ценам или льготные услуги для малообеспеченных, организация бытовых услуг для малоимущих»; 5 \% предпринимателей полагают, что это «бизнес, занимающийся благотворительностью» (это утверждение ошибочно, поскольку самоокупаемость является одним из критериев социального предпринимательства); еще 4,5\% считают, что социальные предприниматели - это «благотворители, спонсоры, меценаты», что также неверно.

На вопрос «Знаете ли Вы людей, которые занимаются социальным предпринима-

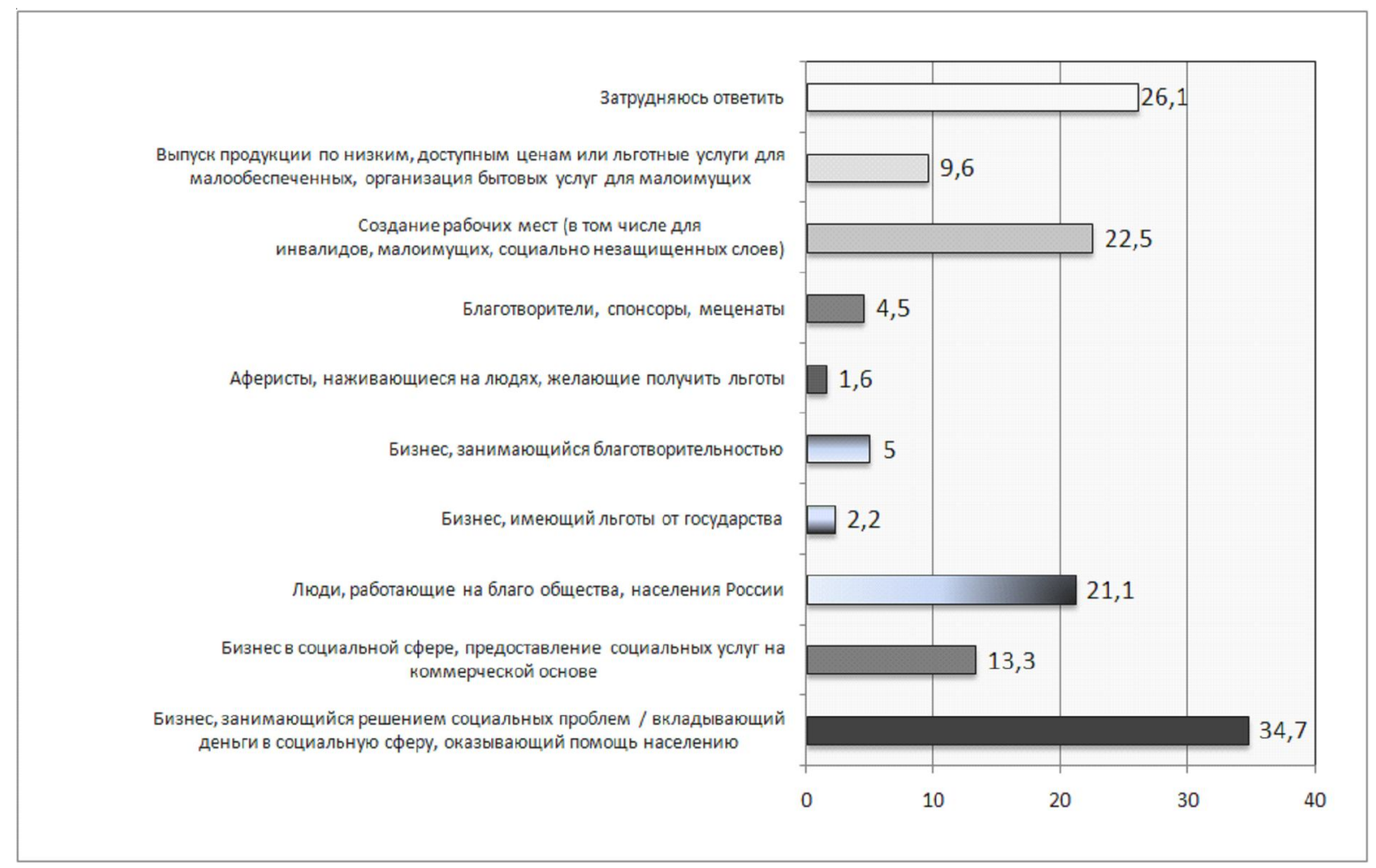

Рис. 3. Распределение ответов на вопрос «Как Вы думаете, что представляет собой социальное предпринимательство?», \%, множественный ответ 
тельством в Вашем городе или области?» более половины опрошенных (53,1 \%) затруднились ответить, что подтверждает гипотезу, что предприниматели не достаточно хорошо знакомы со сферой социального предпринимательства и не могут четко и ясно его идентифицировать (табл. 8).

\section{Таблица 8 \\ Распределение ответов на вопрос «Знаете ли Вы людей, которые занимаются социальным предпринимательством в Вашем городе или области?», \%}

\begin{tabular}{|l|c|}
\hline \multicolumn{1}{|c|}{ Вопрос } & Результат, \% \\
\hline Да, знаю & 7,8 \\
\hline Нет & 39,1 \\
\hline Затруднились ответить & 53,1 \\
\hline
\end{tabular}

Ответили, что не знают людей, занимающихся социальным предпринимательством, $39,1 \%$ респондентов. Только 7,8 \% опрошенных заявили, что знают социальных предпринимателей в Волгоградской области и назвали несколько фамилий. На этот же вопрос респонденты отвечали, называя социальными предпринимателями весь «малый бизнес Волгограда», «продавцов на рынке», сферу бытового обслуживания населения, что является ошибочным мнением. Таким образом, представление о социальном предпринимательстве в среде малого бизнеса Волгоградской области не сформировано. В целом трактовка социального предпринимательства верна, однако для представителей малого и среднего бизнеса характерно непонимание смысла социального предпринимательства.

Выводы. Информированность населения Волгограда о социальном предпринимательстве в целом соотносится с данными всероссийских опросов ЦИРКОН, в которых отмечается низкий уровень информированности населения о социальном предпринимательстве. Можно сделать выводы, что фактор пола практически не влияет на уровень информированности. В то же время наблюдается зависимость от возраста - чем моложе респондент, тем он более информирован, молодежь до 30 лет в два раза чаще отвечала, что знает о социальном предпринимательстве по сравнению с респондентами старше 50 лет.
Род деятельности также влияет на информированность - более осведомлены государственные и муниципальные служащие, обучающиеся, предприниматели, а менее - работники крупных промышленных предприятий, безработные, домохозяйки, работники сферы торговли и услуг, разница в информированности в два и более раз.

Отмечено, что уровень материального благосостояния также связан с информированностью о социальном предпринимательстве. Среди тех респондентов, кто не испытывает материальных затруднений, знает о социальном предпринимательстве каждый пятый, а среди нуждающихся в несколько раз меньше - каждый двадцатый.

В определения социального предпринимательства, которые давали участники опроса, вкладываются довольно разные смыслы от коммерческой деятельности, ориентированной на доход и выгоду, до благотворительности и меценатства. Таким образом, в массовом сознании населения Волгограда отсутствует четко сформированное представление о социальном предпринимательстве. Наиболее часто встречающиеся трактовки связаны с указанием на социальную миссию, самоокупаемость, и финансовая устойчивость отмечается гораздо реже, а инновации совсем не соотносятся населением с социальным предпринимательством.

В представлении молодых волгоградцев до 24 лет около половины опрошенных считают, что НКО поступают правильно, когда предоставляют свои услуги платно и ведут предпринимательскую деятельность. Однако чем старше респонденты, тем менее склонны они считать, что НКО должны предоставлять платные услуги - среди 50-59-летних так считает одна треть респондентов, а свыше 60 лет - только четверть опрошенных.

Среди малых предпринимателей Волгоградской области социальное предпринимательство если не terra incognito, то не совсем ясная сфера деятельности. Более четверти опрошенных затруднились определить, что представляет собой социальное предпринимательство. Большинство предпринимателей считают, что это бизнес, занимающийся решением социальных проблем и вкладывающий деньги в социальную сферу, что являет- 
ся верной трактовкой. Однако встречаются и неверные мнения, отождествляющие социальное предпринимательство с благотворительностью и меценатством. Можно предположить, что основная часть предпринимателей вряд ли будут вкладывать и развивать сферу, которая им неизвестна, законодательно не регламентирована и вызывает затруднения в организационных, финансовых, информационных и других вопросах. Развитие социального предпринимательства возможно только при информационной, консультационной поддержке со стороны государства, законодательном оформлении статуса социального предпринимателя, налоговых и имущественных преференциях.

\section{ПРИМЕЧАНИЕ}

1 Работа выполнена в рамках научного проекта № 17-13-34010 «Ресурсный потенциал некоммерческих организаций в сфере социального предпринимательства» при финансовой поддержке РФФИ и Администрации Волгоградской области.

\section{СПИСОК ЛИТЕРАТУРЫ}

1. Баталина, М. Обзор опыта и концепций социального предпринимательства с учетом возможностей его применения в современной России : препринт WP1/2008/02 / М. Баталина, А. Московская, Л. Тарадина. - М. : Изд-во ГУ ВШЭ, 2008. - $84 \mathrm{c}$.

2. Московская, А. А. Между социальным и экономическим благом: конфликт проектов легитимации социального предпринимательства в России / А. А. Московская, А. А. Берендяев, А. Ю. Москвина // Мониторинг общественного мнения: экономические и социальные перемены. - 2017. № 6. - С. 31-51.

3. Организация экономического сотрудничества и развития (ОЭСР). - Электрон. текстовые дан. Режим доступа: http://www.oecd.org/cfe/leed/ socialentrepreneurship-oecd-ec.htm (дата обращения: 10.09.2018). - Загл. с экрана.

4. Социальное предпринимательство в России и в мире. Практика исследования / отв. ред. А. А. Московская. - М. : Изд. дом Высшей школы экономики, 2011. - 284 с.

5. ЦИРКОН. Нуждается ли социальное предпринимательство в общественном доверии? Пресс- релиз, 22.11.2016. - Электрон. текстовые дан. - Режим доступа: http:/www.zircon.ru/upload/iblock/ff6/ SP_PR 2016.pdf(дата обращения: 10.09.2018)-Загл. с экрана.

6. ЦИРКОН. Россияне по-прежнему не знают, что такое социальное предпринимательство. Электрон. текстовые дан. - Режим доступа: http: //www.zircon.ru/upload/iblock/a 1 c/Socialnoe predprinimatelstvo PR 13-07-11.pdf(дата обращения: 10.09.2018). - Загл. с экрана.

7. ЦИРКОН. Социальное предпринимательство: восприятие россиян. - Электрон. текстовые дан. - Режим доступа: http://www.zircon.ru/upload/ iblock/737/Socialnoe_predprinimatelstvo_2012.ppt (дата обращения: 10.09.2018). - Загл. с экрана.

8. ЦИРКОН. Социальное предпринимательство: восприятие россиян: по результатам массовых опросов населения РФ (2008-2016). - Электрон. текстовые дан. - Режим доступа: http://www. zircon.ru/upload/iblock/a lc/Socialnoe predprinimatelstvo_PR_13-07-11.pdf(дата обращения: 10.09.2018). - Загл. с экрана.

9. ЦИРКОН. Социальный предприниматель 2018. Автопортрет. Аналитический отчет по результатам исследования. - Электрон. текстовые дан. Режим доступа: http://www.zircon.ru/upload/iblock/ 4e7/socialnyj_predprinimatel_2018_avtoportret.pdf (дата обращения: 10.09.2018). - Загл. с экрана.

10. Alter, S. K. Social Enterprise Typology / S. K. Alter. - Virtue Ventures LLC. Nov. 27, 2007. $124 \mathrm{p}$.

11. Robinson, J. Navigating Social and Institutional Barriers to Markets: How Social Entrepreneurship Identify and Evaluate Opportunities / J. Robinson // Social Entrepreneurship. Basingstoke : Palgrave Macmillan, 2006. - P. 95-120.

\section{REFERENCES}

1. Batalina M., Moskovskaya A., Taradina L. Obzor opyta $i$ kontseptsiy sotsialnogo predprinimatelstva $s$ uchetom vozmozhnostey ego primeneniy a $v$ sovremennoy Rossii: preprint WP1/2008/02 [Review of Experience and Conceptions of Social Entrepreneurship Taking into Account the Possibilities of Its Application in Modern Russia: Preprint WP1/2008/02]. Moscow, GU VShE Publ., 2008. 84 p.

2. Moskovskaya A.A., Berendyaev A.A., Moskvina A.Yu. Mezhdu sotsialnym i ekonomicheskim blagom: konflikt proektov legitimatsii sotsialnogo predprinimatelstva v Rossii [Between the Social and Economic Good: Conflicting Projects of Legitimation of Social Entrepreneurship in Russia]. Monitoring obshchestvennogo mneniya: ekonomicheskie $i$ sotsialnye peremeny, 2017, no. 6, pp. 31-51. 
3. Organizatsiya ekonomicheskogo sotrudnichestva i razvitiya [Organization for Economic Cooperation and Development]. URL: http://www. oecd.org/cfe/leed/socialentrepreneurship-oecd-ec.htm (accessed 10 September 2018).

4. Moskovskaya A.A., ed. Sotsialnoe predprinimatelstvo $v$ Rossii $i v$ mire. Praktika issledovaniya [Social Entrepreneurship in Russia and Worldwide. Research Practice]. Moscow, GU VShE Publ., 2011. 284 p.

5. ZIRCON. Nuzhdaetsya li sotsialnoe predprinimatelstvo $v$ obshchestvennom doverii? Press-reliz, 22.11.2016 [Does Social Entrepreneurship Need Public Trust? Press Release of 22 November 2016]. URL: http://www.zircon.ru/ upload/iblock/ff6/SP_PR_2016.pdf (accessed 10 September 2018).

6. ZIRCON. Rossiyane po-prezhnemu ne znayut, chto takoe sotsialnoe predprinimatelstvo [Russians Still Don't Know What Social Entrepreneurship Is]. URL: http://www.zircon.ru/upload/iblock/a1 c/ Socialnoe_predprinimatelstvo_PR_13-07-11.pdf (accessed 10 September 2018).

7. ZIRCON. Sotsialnoe predprinimatelstvo: vospriyatie rossiyan [Social Entrepreneurship:
Russians'Attitude]. URL: http://www.zircon.ru/upload/ iblock/737/Socialnoe_predprinimatelstvo_2012.ppt (accessed 10 September 2018).

8. ZIRCON. Sotsialnoe predprinimatelstvo: vospriyatie rossiyan: po rezultatam massovykh oprosov naseleniya RF (2008-2016) [Social Entrepreneurship: Russians' Attitude according to the Results of Mass Surveys of the Russian Population]. URL: http://www.zircon.ru/upload/iblock/a1c/ Socialnoe_predprinimatelstvo_PR_13-07-11.pdf (accessed 10 September 2018).

9. ZIRCON. Sotsialnyy predprinimatel -2018 . Avtoportret. Analiticheskiy otchet po rezultatam issledovaniya [Social Entrepreneur-2018. Selfportrait. Analytical Report Based on the Results of the Study]. URL: http://www.zircon.ru/upload/iblock/4e 7/ socialnyj_predprinimatel_2018_avtoportret.pdf (Accessed September 10, 2018).

10. Alter S.K. Social Enterprise Typology. Virtue Ventures LLC, November 27, 2007. 124 p.

11. Robinson J. Navigating Social and Institutional Barriers to Markets: How Social Entrepreneurship Identify and Evaluate Opportunities. Social Entrepreneurship. Basingstoke, Palgrave Macmillan, 2006, pp.95-120.

\section{Information about the Author}

Mariya B. Poltavskaya, Candidate of Sciences (Sociology), Associate Professor of Department of Sociology, Volgograd State University, Prosp. Universitetsky, 100, 400062 Volgograd, Russian Federation, poltavskaya@volsu.ru.

\section{Информация об авторе}

Мария Борисовна Полтавская, кандидат социологических наук, доцент кафедры социологии, Волгоградский государственный университет, просп. Университетский, 100, 400062 г. Волгоград, Российская Федерация, poltavskaya@volsu.ru. 